\title{
Paediatric caecal volvulus with perforation and faecal peritonitis
}

\author{
Ramnik V Patel, ${ }^{1,2}{ }^{2}$ ke Njere, ${ }^{3}$ Dhaval Govani, ${ }^{4}$ Richard Stewart ${ }^{5}$
}

${ }^{1}$ Department of Paediatric Urology, University College London Hospitals NHS Foundation Trust, London, UK ${ }^{2}$ Department of Paediatric Urology, Great Ormond Street Children Hospital NHS Trust, London, UK

${ }^{3}$ Department of Paediatric Surgery, HRI, Hull, UK

${ }^{4}$ Birmingham Medical School, Birmingham, UK

${ }^{5}$ Department of Paediatric Surgery, QMC, Nottingham, UK

\section{Correspondence to}

Ramnik V Patel, ramnik@doctors.org.uk

Accepted 10 July 2014

\section{DESCRIPTION}

A 7-year-old boy presented to the paediatric department of district general hospital with persistent and diffuse abdominal pain, bilious vomiting, constipation and abdominal distention of about $24 \mathrm{~h}$ duration. $\mathrm{He}$ had a background of prematurity, developmental delay, and chronic constipation with chronic recurrent unexplained abdominal pain. $\mathrm{He}$ had undergone an uneventful percutaneous endoscopic gastrostomy 5 years ago for feeding difficulty and failure to thrive. During the abdominal examination, a palpable, firm and tympanitic mass was identified in the mid-portion of the upper abdomen, and diffuse tenderness with peritoneal irritation was noted. The plain radiographs of the abdomen showed a prominent segment of dilated intestine suggestive of volvulus (figure 1A, B). His general condition suddenly became poor and was referred to us. He was resuscitated and transferred to us after stabilisation. Chest radiograph in upright position showed saddle bag sign with gross pneumoperitoneum. The patient underwent an urgent exploratory laparotomy, with findings at the operation showing axial rotation of the caecum with gangrene, perforation and large subserosal pneumatocele. The operative treatment consisted of resection of the terminal ileum and caecum followed by primary ileo-ascending anastomosis. The patient had uneventful recovery postoperatively. He was asymptomatic at 1 year follow-up. Caecal volvulus is very rare in paediatric age and is considered as one of the manifestations of intestinal malrotation and malfixation anomalies. ${ }^{1} 2$ Diagnostic uncertainty and delay is usual and no consensus on treatment modalities including conservative, de-volvulus only, de-volvulus with caecopexy, appendicular stump caecostomy and resection with anastomosis have been suggested. Resection and primary anastomosis has the best long-term results. ${ }^{1-3}$

\section{Learning points}

- Caecal volvulus with perforation and faecal peritonitis is extremely rare and is a potential lethal emergency in children.

- Preoperative diagnosis is unlikely as general condition of the patient is poor for any cross-sectional imaging and a low threshold for intervention leads to operative diagnosis.

- There is no other option except resection and anastomosis or a staged reconstruction if the general condition of child is poor and incidentally that is the procedure having highest success rates in long-term.
A

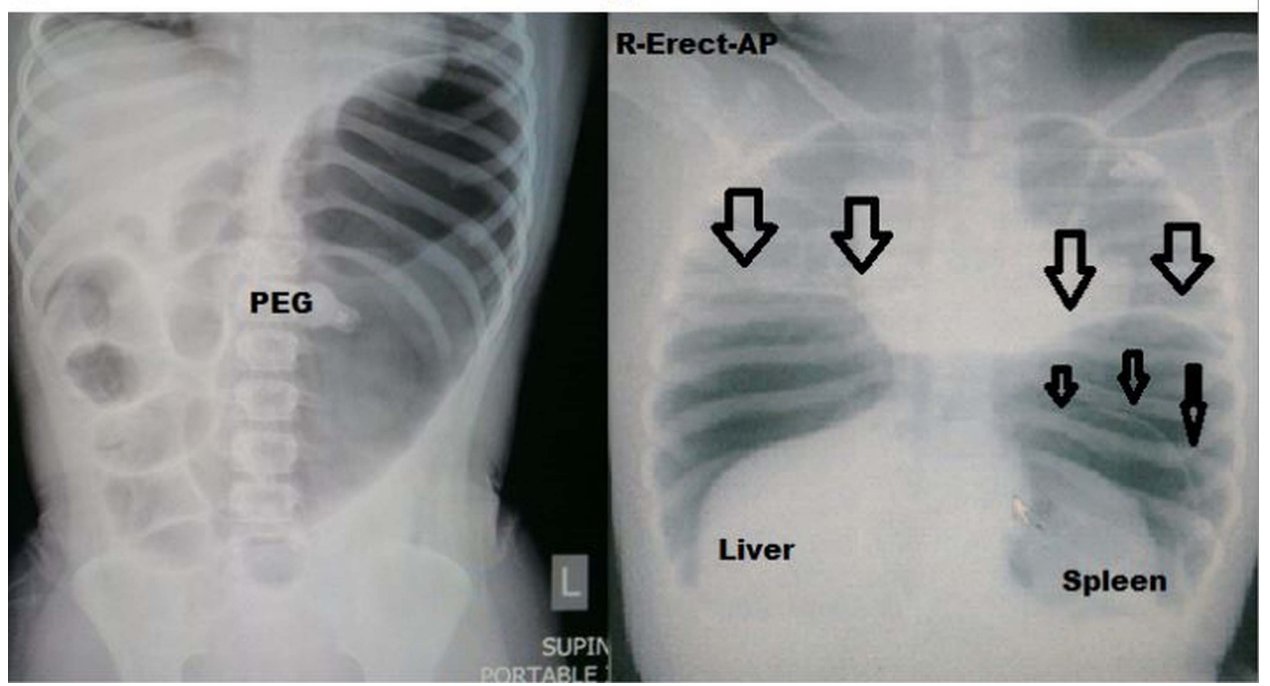

Figure 1 (A) Plain abdominal radiograph showing abnormal gas in the central and left upper abdomen. (B) An erect chest radiograph at arrival showing massive pneumoperitoneum with saddle bag sign (wide arrows), note massive caecal pneumatosis seen as thin line in left upper abdomen (thin dark arrows; AP, anteroposterior; PEG, percutaneous endoscopic gastrostomy).
Govani D, et al. BMJ Case Rep Published online:

[please include Day Month Year] doi:10.1136/bcr-2014205511 
Contributors All the authors have made substantial contributions to the conception and design of this manuscript, search of literature, the acquisition, analysis and interpretation of the data, to drafting the manuscript or revising it critically for important intellectual content, and to the final approval of the version to be published.

Competing interests None.

Patient consent Obtained.

Provenance and peer review Not commissioned; externally peer reviewed.

\section{REFERENCES}

1 Zakeri SA, Hotouras A, Mukhtar $\mathrm{H}$, et al. Caecal volvulus following abdominoplasty: a tale of caution. BMJ Case Rep 2014: Published online 23 January 2014. doi: 10. 1136/bcr-2013-202614

2 Kokoska ER, Herndon CD, Carney DE, et al. Cecal volvulus: a report of two cases occurring after the antegrade colonic enema procedure. J Pediatr Surg 2004:39:916-19.

3 Consorti ET, Liu TH. Diagnosis and treatment of caecal volvulus. Postgrad Med J 2005:81:772-6.

Copyright 2014 BMJ Publishing Group. All rights reserved. For permission to reuse any of this content visit http://group.bmj.com/group/rights-licensing/permissions.

BMJ Case Report Fellows may re-use this article for personal use and teaching without any further permission.

Become a Fellow of BMJ Case Reports today and you can:

- Submit as many cases as you like

- Enjoy fast sympathetic peer review and rapid publication of accepted articles

- Access all the published articles

- Re-use any of the published material for personal use and teaching without further permission

For information on Institutional Fellowships contact consortiasales@bmjgroup.com

Visit casereports.bmj.com for more articles like this and to become a Fellow 